UDC 613.6.027

DOI: $10.21668 /$ health.risk/2020.3.16.eng

Research article

\title{
ANALYSIS OF INDIVIDUAL OCCUPATIONAL HEALTH RISKS FOR WORKERS WITH BASIC OCCUPATIONS TYPICAL FOR OIL PROCESSING ENTERPRISES
}

\author{
N.P. Setko, S.V. Movergoz, E.V. Bulycheva \\ The Orenburg State Medical University, 6 Sovetskaya Str., Orenburg, 460000, Russian Federation
}

At present a systemic approach based on occupational risk assessment methodology is a key to adequate detection of cause-and-effect relations between a disease and working conditions.

Our research goal was to calculate and assess individual occupational health risks for operators and drivers employed at an oil processing enterprise.

Our research object were parameters revealed via special assessment of working conditions and data obtained via periodical medical examinations performed on 198 operators and 160 drivers employed at an oil processing enterprise.

A procedure for calculating individual occupational health risks took into account working conditions, individual health, working experience, and workers' age. Influence exerted by working experience duration on health of workers from the examined occupational groups was estimated in three groups: working experience shorter or equal to 5 years; working experience equal to 6-10 years; working experience being longer than 10 years. Integral assessment of working conditions was obtained taking into account impacts exerted by occupational factors with different hazard categories, assessed risks of injuries and assessment of workers' protection with individual protection means. We calculated integral parameters of working conditions assessment, hazard parameters at workplaces, and one-number integral values of individual occupational risks.

We determined that $91 \%$ drivers and $34.9 \%$ operators ran high and extremely high occupational risks of diseases; those risks changed individually depending on hazard occupational factors at workplaces, age, working experience, and a worker's health. It was shown that high individual occupational risks were much more frequent among drivers and operators with long working experience (6-10 years and longer) who had III-IV health groups and worked under hazardous conditions.

Key words: occupational hazard, integral assessment of working conditions, operators, drivers, Individual occupational risks.

There have been significant achievements in occupational hygiene and workers' health protection that allow preventing injuries and morbidity among employable population. Despite that, a lot of industrial enterprises still face serious problems related to managing health risks for workers $[1,2]$. Occupational risks create substantial threats for workers' health and working capacities, equipment, and working environment; they produce adverse effects on competitiveness and economic performance indicators in a brunch. Occupational diseases and industrial accidents lead to grave social, economic, and medical consequences [3]. According to international statis- tic data, occupational diseases and industrial accidents result in almost 2.5 million deaths per year and in more than 2.8 trillion USD expenses all over the world [4]. These data clearly indicate that health risks for workers are a serious problem and are subject to proper regulation [5]. Raising awareness among workers about adverse outcomes occupational diseases and industrial accidents might have has led to more efficient implementation of prevention activities aimed at reducing occupational health risks [6, 7]. Given that, OHSMS (Occupational Health and Safety Management Systems) are being actively implemented in many countries all over the

(C) Setko N.P., Movergoz S.V., Bulycheva E.V., 2020

Nina P. Setko - Doctor of Medical Sciences, Professor, Head of the Preventive Medicine Department (e-mail: nina.setko@gmail.com; tel.: +7 (3532) 50-06-06 (ext. 612); ORCID: https://orcid.org/0000-0001-6698-2164).

Sergei V. Movergoz - Candidate of Medical Sciences, Associate Professor (e-mail: k_epidem.fpdo@orgma.ru; tel.: +7 (3532) 50-06-06 (ext. 402); ORCID: http://orcid.org/0000-0002-9724-8672).

Ekaterina V. Bulycheva - Candidate of Medical Sciences, Assistant Professorat the Preventive Medicine Department (e-mail: e-sosnina@mail.ru; tel.: +7 (3532) 50-06-06 (ext. 642); ORCID: https://orcid.org/0000-0002-2915-2046). 
world as they are an efficient tool that allows industrial enterprises to manage their occupational risks and to control problems existing in labor protection $[8,9]$. Such a system focuses on occupational safety at workplaces whereas contemporary issues indicate it is also necessary to take medical aspects into account [10]. International practices in occupational risks assessment and management at workplaces are actively involving a system for Personal Exposure Monitoring; its fundamental role is to comprehensively assess not only physical, chemical, biological and ergonomic target threats but also medical factors determining how sensitive workers' bodies are to occupational hazards $[10,11]$. However, up to now experts have still been searching for efficient approaches and techniques that can be used to quantitatively assess occupational health risks for workers ${ }^{1}$ [12-14].

In domestic studies recently there has been search for efficient systems aimed at managing occupational health risks for workers via influencing exposure to occupational factors, their intensity, and taking into account individual sensitivity of a specific worker's body to occupational hazards [15-17]. Quantitative calculation of damage to a worker's health that can occur during his or her occupational activities is considered an efficient procedure within a systemic approach to managing occupational health risks at production ${ }^{2}$ [18-20]. Prediction given for preservation of a worker's life span, health, functional abilities, and his or her children's health is considered a key criterion in quantitative health risk assessment ${ }^{3,4}$.

Our research goal was to calculate and assess individual occupational health risks for operators and drivers employed at an oil processing enterprise.
Data and methods. Individual occupational health risks were assessed for 198 operators and 160 drivers employed at an oil processing plant; the assessment was performed as per the procedure developed by N.F. Izmerov, L.V. Prokopenko, N.I. Simonova et al. (2010) and approved by the Scientific Council held by the RF Public Healthcare Ministry and Russian Academy of Medical Sciences «Medical and ecological issues for employable population» [20]. Individual occupational risks were calculated basing on results obtained via assessing working conditions at a workplace, workers' health at the beginning of the year, their age and working experience as well as data on injuries and occupational morbidity among operators and drivers. Occupational factors influencing operators and drivers were examined as pre data obtained via special assessment of working conditions and workers' health examined during periodical medical examinations. Influence exerted on health of workers from the examined occupational groups by length of their working experience was estimated in three groups, workers with working experience up to 5 years; the $2^{\text {nd }}$ group, $6-10$ years; the $3^{\text {rd }}$ group, longer than 10 years. One-figure value of an individual occupational risk (IOR) was calculated via multiplying summed weighted values of parameters (working conditions assessment, operators' and drivers' working experience, workers' age, and workers' health) reduced to relative values by indexes showing injuries and occupational morbidity at workplaces (1):

$$
\begin{gathered}
\mathrm{IOR}=\left(\mathrm{w}_{\mathrm{i}} \mathrm{K}_{\mathrm{i}} \mathrm{IAWC}+\mathrm{w}_{3} \mathrm{k}_{3} \mathrm{He}+\right. \\
\left.+\mathrm{w}_{\mathrm{B}} \mathrm{k}_{\mathrm{B}} \mathrm{A}+\mathrm{w}_{\mathrm{c}} \mathrm{k}_{\mathrm{c}} \mathrm{WE}\right) \mathrm{I}_{\mathrm{in}} \cdot \mathrm{I}_{\mathrm{om}}
\end{gathered}
$$

where:

IAWC is integral assessment of working conditions at a workplace;

\footnotetext{
${ }^{1}$ CCPS.Guidelines for Hazard Evaluation Procedures. New York, American Institute of Chemical Engineers Publ., 2008, 576 p. (in Russian)

${ }^{2}$ Occupational health risks for workers: guide. In: N.F. Izmerov, E.I. Denisov eds. Moscow, Trovant Publ., 2003,448 p. (in Russian).

${ }^{3}$ A procedure for calculating individual occupational risks depending on working conditions and workers' health: methodical guidelines. In: N.F. Izmerov, L.V. Prokopenko, N.I. Simonova [et al.] eds. Moscow, 2012, 29 p. (in Russian).

${ }^{4}$ A procedure for calculating individual occupational risks depending on working conditions and workers' health: methodical guidelines. Approved by the Chairman of the Scientific Council No. 45 held by the RF Public Healthcare Ministry and Russian Academy of Medical Sciences «Medical and ecological health issues for employable population». Moscow, 2011,20 p. (in Russian).
} 
He is workers' health;

A is workers' age

WE is working experience;

$\mathrm{I}_{\text {in }}$ is index showing injuries at a workplace;

$\mathrm{I}_{\mathrm{om}}$ is an index showing occupational morbidity at workplace;

$\mathrm{W}_{\mathrm{i}}, \mathrm{W}_{3}, \mathrm{~W}_{\mathrm{B}}, \mathrm{W}_{\mathrm{c}}$ are weighted coefficients that allow taking significance of certain parameters into account;

$\mathrm{k}_{\mathrm{i}}, \mathrm{k}_{3}, \mathrm{k}_{\mathrm{B}}, \mathrm{k}_{\mathrm{c}}$ are coefficients used to recalculated parameters from their absolute values into relative ones.

Integral assessment of working conditions (IAWC) at operators' and drivers' workplaces was performed taking into account exposure to occupational factors with different hazard categories, assessing risks of injuries, and assessing workers' protection with personal protective equipment depending on hazard index (HI) values as per the formula (2):

$$
\mathrm{IAWC}=\frac{100 \cdot[(\mathrm{HI}-1) \cdot 6+\mathrm{R}]}{2334}
$$

where:

$\mathrm{HI}$ is a calculated hazard index for working conditions at a specific workplace;

$\mathrm{R}$ is a rank determined in accordance with injuries risks (IR) and protection assessment (PA) for a specific workplace;

100 is a proportionality coefficient;

2334 is a number that characterizes all theoretically possible combinations of HI, IR, and PA values.

We calculated how hazardous operators' and drivers' working conditions were following a certain sequence via determining total hazard $(\mathrm{TH})$ :

$$
\mathrm{TH}=\sum^{\mathrm{m}} \mathrm{Vi}
$$

where:

$\mathrm{m}$ is a number of occupational factors existing at a workplace;

$\mathrm{Vi}$ is a score number that depends on working conditions category for the i-th occupational factor existing at a workplace.

Then, we calculated total scores (TS) for a workplace:

$$
\mathrm{TS}=2 \cdot \mathrm{m},
$$

where $\mathrm{m}$ is a number of occupational factors existing at a workplace.

Then we calculated working conditions hazard $(\mathrm{WCH})$ as per the following formula:

$$
\text { WCH (TH-TS)/2, }
$$

where $\mathrm{TH}$ and TS were calculated as per the formulas given above, and

2 is a coefficient equal to 2 scores and used to transfer Hi into a dimensionless value.

Integral assessment of working conditions gave us the following ranks for working conditions:

IAWC $\leq 0.04$ means working conditions are acceptable;

IAWC 0.04-0.51, hazardous;

IAWC $0.52-1.54$, extremely hazardous;

IAWC 1.55-3.60, unacceptably hazardous;

IAWC 3.61-7.50, dangerous;

IAWC $\geq 7.50$, extremely dangerous.

One-figure integral values of individual occupational risk were estimated as per the following scale:

$\mathrm{IOR}=0.13$ means low risk;

$\mathrm{IOR}=0.13-0.21$, average risk;

$\mathrm{IOR}=0.22-0.39$, high risk;

IOR $\geq 0.4$, extremely high risk.

Statistical analysis was performed with Statistica 12/0 applied software for Windows. Numerical data are given as simple mean and its standards error $(M \pm m)$. To reveal statistically significant discrepancies between the examined groups, we applied Student's parametric procedure with coefficient calculation and a non-parametric procedure with Mann-Whitney coefficient determination. Discrepancies were considered statistically significant at $p \leq 0.05$.

Results and discussion. We determined that integral hazard index (HI) amounted to $1.6 \pm 1.8$ scores at operators' workplaces, and to $2.4 \pm 2.1$ scores at drivers; workplaces $(p \leq 0.05)$ and was considered to be dangerous. HI was determined at operators' workplaces by such occupational factors as microclimate, infrasound, and labor hardness that were considered to be optimal (2.0 hazard category) and corresponded to 6 scores; elec- 
tromagnetic radiation and noise belonged to 3.1 hazard category (hazardous working conditions) and corresponded to 8 scores; chemical factor and labor intensity belonged to 3.2 hazard category and corresponded to 10 scores (Figure 1). Hazard index at drivers' workplaces was determined by labor intensity (hazard category 2.0, 2 scores); microclimate, electromagnetic radiation, and labor hardness belonging to 3.1 hazard category (12 scores); chemical factor, noise, and infrasound (3.2 hazard category, 24 scores).

Working conditions as their integral assessment (IAWC) revealed turned out to be hazardous and amounted to $0.38 \pm 0.0006$ units for operators and to $0.43 \pm 0.005$ units for drivers, $p \leq 0.05$. Basing on initial data obtained via integral assessment of working conditions, workers' health, age, and working experience, we calculated individual occupational risks (Figure 2). We determined that $55 \%$ operators ran average occupational risks; $32 \%$, high occupational risks; $2.9 \%$, extremely high occupational risks; and only $10.1 \%$ operators ran low individual occupational risks. It is important to note that $78.6 \%$ drivers ran extremely high occupational risks, and only (\% ran average risks; there were no drivers who ran low individual occupational risks.

Analysis of data given in Table 1 revealed that individual occupational risk for workers from the examined occupational groups grew depending on their working experience in the sphere and at the examined enterprise. It was shown that individual occupational health risks grew for both operators and drivers as their working experience got longer. Thus, $64.0 \%$ operators with their working experience at the examined enterprise being shorter than 5 years ran low individual occupational risks; $28.2 \%$, high risks; and only $7.8 \%$, high risks. There was a 1.2-time growth in number of operators running high individual occupational risks among those with working experience being form 6 to 10 years $(15.1 \%$ of the examined workers); and $1.9 \%$ operators in this group ran extremely high occupational health risks. As working experience exceeded 10 years, there was a 2-time growth in a number of operators who ran high occupational health risks.

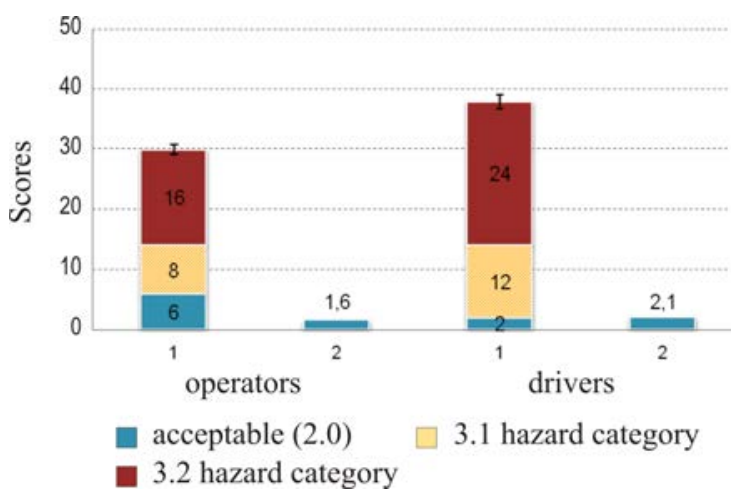

Figure 1. Weighted values of occupational factors (1) and hazard indexes (2) at operators' and drivers' workplaces

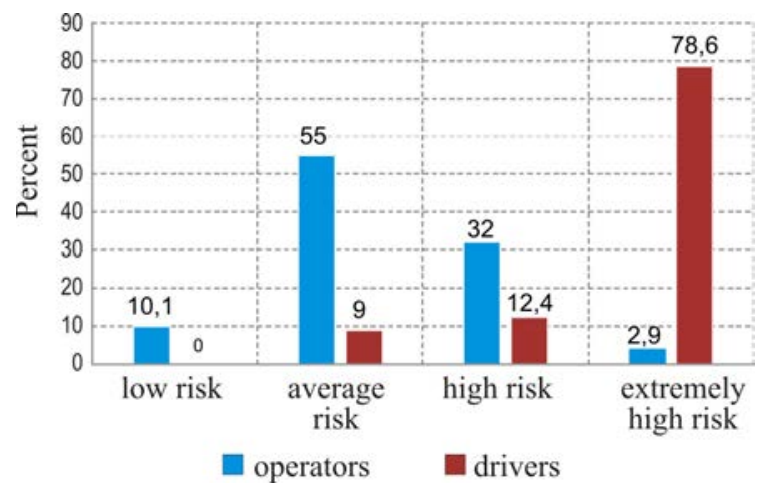

Figure 2. Operators and drivers distributed depending on their individual occupational risks

Table 1

Workers running different individual occupational risks and distributed depending on their working experience (\%)

\begin{tabular}{|c|c|c|c|}
\hline \multirow[b]{2}{*}{$\begin{array}{c}\text { Individual } \\
\text { occuaptional risk }\end{array}$} & \multicolumn{3}{|c|}{ Working experience } \\
\hline & $\begin{array}{l}\text { Shorter } \\
\text { than } \\
5 \text { years }\end{array}$ & $\begin{array}{l}6-10 \\
\text { years }\end{array}$ & $\begin{array}{l}\geq 10 \\
\text { years }\end{array}$ \\
\hline \multicolumn{4}{|c|}{ Operators } \\
\hline Very low & - & - & - \\
\hline Low & 64.0 & 22.6 & 31.5 \\
\hline Average & 28.2 & 60.4 & 35.2 \\
\hline High & 7.8 & 15.1 & 32.4 \\
\hline Extremely high & - & 1.9 & 0.9 \\
\hline \multicolumn{4}{|c|}{ Drivers } \\
\hline Very low & - & - & - \\
\hline Low & - & - & - \\
\hline Average & 24.0 & 15.8 & 3.8 \\
\hline High & 38.0 & 26.3 & 3.8 \\
\hline Extremely high & 38.0 & 57.9 & 92.4 \\
\hline
\end{tabular}


Unlike operators, $76 \%$ drivers with short working experience (shorter than 5 years) ran high and extremely high occupational risks, and only $24 \%$ drivers in this group ran average occupational health risk. Occupational health risks for drivers also grew as their working experience got longer and the growth rate was more significant than for operators. Thus, $57.9 \%$ drivers with working experience being 6-10 years ran extremely high occupational risks, and the figure was much higher $(92.4 \%)$ among drivers with working experience exceeding 10 years (Table 1).

We determined that workers' health was significant for individual occupational risk. It was detected that $73 \%$ operators and $43 \%$ drivers belonged to I and II health groups as per data obtained via periodical medical examinations (Figure 3).

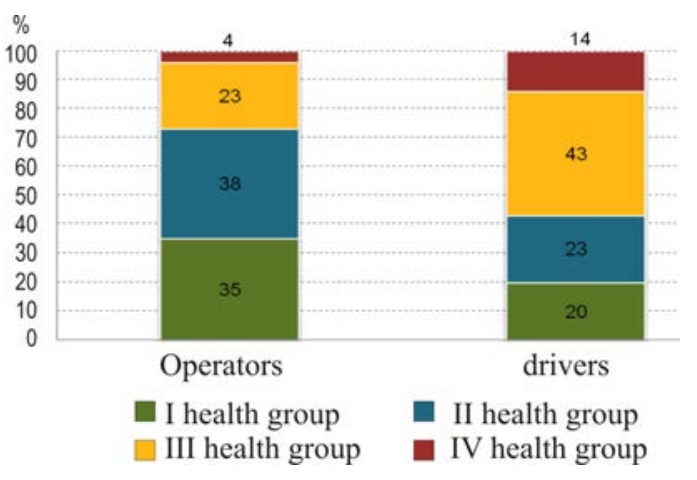

Figure 3. Workers distributed depending on their health group

Workers from I health group didn't have any complaints about their health, their case histories didn't contain any data on any disease or functional disorders and periodical medical examinations didn't reveal them either. Such workers fell sick not more than 2 times a year and it was usually a respiratory disease; overall duration of temporary disability for workers from this health group amounted up to 7 days per year. Workers who had certain functional disorders and therefore ran a risk of a disease occurrence belonged to II health group; they fell sick with respiratory diseases more than 2 times a year, and their temporary disability varied from 7 to 14 days a year. At the same time, $43 \%$ drivers and $23 \%$ operators belonged to III health group. They all had a compensated non-communicable chronic disease; they had a respiratory disease 2 or 3 times a year; and their temporary disability varied from 14 to 21 day. All this, together with impacts exerted by adverse occupational factors and long working experience, resulted in high and extremely high occupational health risks for workers form this health group.

\section{Conclusions.}

1. According to integral assessment, working conditions for operators and drivers are hazardous. Integral hazard index was 1.3 times higher for drivers' workplaces than for operators' ones and it was determined by such adverse occupational factors as noise, infrasound, air being contaminated with a set o adverse chemicals, unfavorable microclimate, and significant labor hardness.

2. It was shown that $34.9 \%$ operators and $9 \%$ drivers ran high and extremely high individual occupational health risk that changed depending on occupational factors hazards at workplaces, working experience, workers' age and health.

3. Individual occupational health risks were more frequent among drivers and operators with long working experience, workers belonging to III-IV health groups, and workers who were exposed to not less than 3 adverse occupational factors belonging to 3.2 hazard category.

4. Therefore, our calculation results and results obtained via analyzing individual occupational health risks for operators and drivers are a basic instrument for substantiating, developing, and selecting a sequence for implementation of managerial decisions necessary to reduce occupational health risks and to preserve workers' health.

Funding. The research was not granted any sponsor support.

Conflict of interests. The authors declare there is no any conflict of interests. 


\section{References}

1. Integrated Occupational Safety and Health Management: Solutions and Industrial Cases. In: S. Väyrynen, K. Häkkinen, T. Niskanen eds. Cham, Springer International Publishing Switzerland Publ., 2015, pp. 157-184.

2. Bes'ko V.A., Ignatova T.V., Mekhant'eva L.E., Shabaeva O.N. Upravlenie professional'nymi riskami na primere promyshlennogo kompleksa [Occupational risks management at an industrial complex]. Professiya i zdorov'e: Materialy V Vserossiiskogo Kongressa. Moscow, 2006, pp. 163-165 (in Russian).

3. Fernandez-Muniz B., Montes-Peon J.M., Vazquez-Ordas C.J. Relation between occupational safety management and firm performance. Saf. Sci, 2009, no. 47, pp. 980-991. DOI: 10.1016/j.ssci.2008.10.022

4. Takala J., Hämäläinen P., Saarela K.L., Yun L.Y., Manickam K., Jin T.W., Heng P., Tjong C. [et al.]. Global estimates of the burden of injury and illness at work in 2012. J. Occup. Environ. Hyg., 2014, vol. 11, no. 5, pp. 326-337. DOI: 10.1080/15459624.2013.863131

5. Mohammadfam I., Kamalinia M., Momeni M., Golmohammadi R., Hamidi Y., Soltanian A. Evaluation of the Quality of Occupational Health and Safety Management Systems Based on Key Performance Indicators in Certified Organizations. Saf. Health Work, 2017, vol. 8, no. 2, pp. 156-161. DOI: 10.1016/j.shaw.2016.09.001

6. Beatriz F.M., Montes-Peon J.M., Vazquez-Ordas C.J. Safety management system: Development and validation of a multidimensional scale. Journal of Loss Prevention in the process Industries, 2007, vol. 20, no. 1, pp. 52-68. DOI: 10.1016/j.jlp.2006.10.002

7. Folch-Calvo M., Brocal F., Sebastián M.A. New Risk Methodology Based on Control Charts to Assess Occupational Risks in Manufacturing Processes. Materials (Basel), 2019, vol. 12, no. 22, pp. 3722. DOI: $10.3390 /$ ma12223722

8. Granerud R.L., Rocha R.S. Organisational learning and continuous improvement of health and safety in certified manufacturers. Saf. Sci, 2011, no. 49, pp. 1030-1039. DOI: 10.1016/j.ssci.2011.01.009

9. Ramli A.A., Watada J., Pedrycz W. Possibilistic regression analysis of influential factors for occupational health and safety management systems. Saf. Sci, 2011, no. 49, pp. 1110-1117. DOI: 10.1016/j.ssci.2011.02.014

10. Hashimoto H., Kogi K. Handbook of occupational safety and health. Kawasaki, The Institute for Science of Labor Publ., 2013, pp. 1194-1197 (in Russian).

11. Hashimoto H., Yamada K., Hori H., Kumagai S., Murata M., Nagoya T., Nakahara H., Mochida N. [et al.]. Guidelines for personal exposure monitoring of chemicals: Part VI. J. Occup. Health., 2018, vol. 60, no. 4, pp. 275-280. DOI: 10.1539/joh.2018-0121-RA

12. Khan F., Rathnayaka S., Ahmed S. Methods and models in process safety and risk management: Past, present and future. Proc. Saf. Environ. Protect, 2015, vol. 98, pp. 116-147. DOI: 10.1016/j.psep.2015.07.005

13. Goerlandt F., Khakzad N., Reniers G. Validity and validation of safety-related quantitative risk analysis: A review. Saf. Sci, 2017, vol. 99, pp. 127-139. DOI: 10.1016/j.ssci.2016.08.023

14. Proskovics R., Hutton G., Torr R., Scheu N.M. Methodology for risk assessment of substructures for floating wind turbines. Energy Procedia, 2016, vol. 94, pp. 45-52. DOI: 10.1016/j.egypro.2016.09.189

15. Izmerov N.F. Natsional'nyi proekt «Zdorov'e» - rol' meditsiny truda [«Health» National Project and the role occupational medicine plays in it]. Meditsina truda i promyshlennaya ekologiya, 2007, no. 12, pp. 4-8 (in Russian).

16. Izmerov N.F. Otsenka professional'nogo riska i upravlenie im - osnova profilaktiki v meditsine truda [Occupational risk assessment and management as a basis for prevention in occupational medicine]. Gigiena i sanitariya, 2006, no. 5, pp. 14-16 (in Russian).

17. Maksimov M.S. Healthy worker effect in epidemiological researches. Meditsina $v$ Kuzbasse, 2015, vol. 14, no. 2, pp. 10-16 (in Russian).

18. Setko A.G., Nazmeev M.A., Setko N.P., Lutoshkina A.S. Methodical approaches то an estimation of a functional state of organs and systems of workers at individual professional risk prognosis. Okhrana truda i tekhnika bezopasnosti $v$ uchrezhdeniyakh zdravookhraneniya, 2012, no. 1, pp. 33-37 (in Russian). 
19. Movergoz S.V., Setko N.P., Setko A.G., Bulycheva E.V. Evaluation of occupational risk for health of operators of petrochemical production and their physiological and hygienic stipulation. Gigiena i sanitariya, 2016, vol. 95, no. 10, pp. 1002-1007 (in Russian).

20. Goryaev D.V., Tikhonova I.V., Kir'yanov D.A. Industrial enterprises and health risk categories. Gigiena i sanitariya, 2017, vol. 96, no. 12, pp. 1155-1158 (in Russian).

Setko N.P., Movergoz S.V., Bulycheva E.V. Analysis of individual occupational health risks for workers with basic occupations typical for oil processing enterprises. Health Risk Analysis, 2020, no. 3, pp. 131-137. DOI: 10.21668/health.risk/2020.3.16.eng

Received: 22.04 .2020

Accepted: 21.09.2020

Published: 30.09.2020 